\title{
AHŞAP ESERLERİN KULLANIM ALANLARININ SINIFLANDIRILMASI
}

\author{
The Classification Of The Areas Of Usage Of The Wooden Artefacts \\ Cemile YILDIRIM ALTUN ${ }^{1}$
}

\begin{abstract}
ÖZET
Ahşap, sanat eserlerinin üretimi için insanlık tarihinde en çok kullanılan malzemelerden biri olmuştur. Ahşabın sanat eseri olarak nitelendirilmesi sadece kullanılabilirlik niteliği ile değil, parlaklık, renk, doku, çizgi gibi doğal estetik özellikleri ile de alakalıdır. Ahşabın bu özellikleri nedeniyle herhangi bir çağda ya da kültürel çevrelerde sadece mobilya olarak kullanıldığının sanılması kısıtlı bir bakış açısıdır. Kolay işlenebilirliği, yeniden kullanılabilirliği ahşabı gemilerde, dini objelerde, ev eşyasında, yapı elemanlarında hatta yapıların tamamında kullanıma elverişli hale getirmektedir. İnsanlar tarafından önceleri barınma ihtiyacının karşılanmasında kullanılan ahşap, daha sonraları evlerin dekoratif bölümlerinde, tarım aletlerinde, müzik aletlerinde, dini objelerde, hatta bazı makinelerin ekipmanlarında kullanılmaya başlamıştır. Ahşap eserler, ham süsleme elemanları ya da pigment tabakaları ile renklendirilmiş halde tasarlanmıștır. Bu eserler taşınır ve taşınmaz ahşap eserler olarak iki ana gruba ayırmak mümkündür. Genel olarak taşınamaz eserlerde yapı ve yapı elemanları ham ya da dış etkenlere karşı dayanıklılığını artırıcı koruyucular ile kullanılırken, taşınır kültür varlıkları kompozit yapıları ile çeşitlilik göstermektedir. Ahşap eserlere müdahale ederken kompozit yapıyı oluşturan diğer malzemelere ait bilgi sahibi olmak gerekmektedir. Bu eserler ahşaba ek olarak altın, gümüş, bakır, fildiși, bağa, sedef, pigment tabakası gibi birçok süsleme elemanını ayrı ayrı ya da topluca içerebilmektedir. Ahşap eserlerde malzeme çeşitliliğinin yanı sıra süsleme tekniklerinde de oldukça zengin ve köklü tekniklerin kullanıldığı bilinmektedir. Bu teknikler arasında Türk kültürünün simgeleri haline gelmiş, kündekari, oymacılık, kakmacılık teknikleri akla ilk gelen örneklerdir. $\mathrm{Bu}$ eserlerin restorasyon ve konservasyon işlemlerinde konservatörün, süsleme elemanlarının günümüzdeki ustaları ile malzeme, ișçilik konularında geleneksel el sanatlardaki uzmanlardan da motif özellikleri gibi birçok konu hakkında bilgi alması gerekebilir. Eserin belgeleme ve müdahale aşamalarında birçok disiplin ile ortak hareket edilerek, disiplinler arası bir çalışmanın ortaya çıkarılması gerekmektedir. Eserin mevcut durumu, malzeme, teknik özellikleri, bozulmaların teşhisleri, kullanım amacı, sergi ve depolama koşullarının ortaya en net şekilde çıkarılabilmesi için farklı alanların uzmanları ile birlikte çalışılması oldukça önemlidir. Bu araştırma; kültürel mirasın bir parçası olan ahşabın kullanım alanlarını belirlemek, ahşap konservasyonu konusunda çalışan kişiler için eser çeşitliliğini ve bu eserlerde tercih edilen ahşapların özelliklerini aktarmak amacıyla oluşturulmuş bir derleme çalışmasıdır. Bu amaç doğrultusunda ahşap eserlerle ilgili araştırmalar derlenerek kullanım alanlarının çeşitliliği ve gruplandırılması yapılmıştır.
\end{abstract}

Anahtar Kelimeler: Ahşap, Ahşap Eser, Koruma, Sınıflandırma, Tarihi Eser.
ABSTRACT

Wood is one of the most used materials that were used in the production of artefacts throughout the history of mankind. It is not just the usability that characterizes the wood as an artwork; brightness, color, texture, lines are also effective. Because of these properties of wood, it is a limited view that it is assumed that it is used only as furniture in any era or in cultural environments. Easiness of the workability and the ability to reuse made wood a very favorable material for ships, religious artifacts, home furniture, building elements, even buildings. This study is a compilation, with the intention of determining the areas of usage of the wood which is part of the cultural heritage, transmits the properties of the wood chosen for the artefacts and these artefacts' ranges for people who work on wood's conservation. In accordance with this purpose, the studies about these wood artefacts were gathered and range of areas of usage were grouped. Wood was first used for sheltering by humans and afterwards for decorative products, agricultural implements, music instruments, religious objects, even parts of machine equipment. Wood artefacts come across as crude, raw and ornamental elements or composite materials colored with pigment layering. These artefacts can be divided into two groups as movable and immovable. In general, while building and building elements are used directly in unmovable artifacts or with protectors that increase their resistance against external factors, movable cultural works vary with their composite structures. While interfering with wooden works, it is necessary to have knowledge of other materials that compose the composite structure. In addition to wood, these works can contain many decorative elements such as gold, silver, copper, ivory, tortoiseshell, mother-of-pearl, pigment layer separately or collectively. It is known that in wood artefacts rather rich and essential techniques were being used besides material variety. Among these techniques, kundekari, carving, inlaying which had become tokens of Turkish culture is the first examples that came to mind. During these works' restoration and conservation processes, the conservator needs to know lots of things like techniques of ornamental elements nowadays, materials, the topic of workmanship, specialty of traditional handicrafts and features of motives. There needs to be an interdisciplinary coordination accompanied by various departments during the work's documentation and intervention stages. It is very important to work with experts from different fields in order to present the current state of the work, material, technical features, diagnoses of deterioration, purpose of use, exhibition and storage conditions in the most clear way. This study is a compilation study designed to determine the usage areas of wood, which is a part of cultural heritage, and to convey the diversity of works and the characteristics of the woods preferred in these works for those working on wood conservation. For this aim with this purpose, the researches on woodworks were compiled and the usage moments were diversified and grouped.

Keywords: Wood, Wooden Artefact, Conservation, Classification, Historical Artifacts.
1. ORCID: 0000-0003-1421-2269
1. Doktora Öğrencisi, Ankara Hacı Bayram Veli Üniversitesi, Lisansüstü Eğitim Enstitüsü, Kültür Varlıklarını Koruma Bilim Dalı e-posta: cemileyildirim1987@gmail.com 


\section{EXTENDED ABSTRACT}

It is possible to see wooden materials in most of the historical artifacts that make up the cultural heritage. Not only its usability and working convenience, but also its natural beauty have been a factor in its preference. In addition, the sustainability of wood has caused it to be preferred. In other words, after a tree is cut, another tree to be able to grow in its place enables it to be defined as sustainable and replaceable.

Wooden works that can be exhibited in museums are movable cultural property, but the structural parts are in the group of immovable cultural properties. Wooden works have a wide range of uses, from homes that provide shelter to people, hand tools that make their daily lives easier, musical instruments and firearms.

Wood was first used for sheltering by humans and afterwards for making decorative products, agricultural implements, music instruments, religious objects, even parts of machine equipment. Wood artefacts come across as crude, raw and ornamental elements or composite materials colored with pigments. These artefacts can be divided into two groups as portable and immovable. Even though, in importable works structure and structural elements were used as raw or with protectives that enhance the durability against external factors, in portable cultural works this structure is more rich and composite. While intervening the wood works whose textures are composite, it is necessary to have knowledge on lots of areas to determine the intervention steps. Alongside the wood, these artefacts can be formed by using lots of ornamental elements such as gold, silver, copper, ivory, knot, pearl, pigment layers or one element. It is known that in wood artefacts rather rich and essential techniques were being used besides material variety. Among these techniques, kundekari, carving, inlaying which had become tokens of Turkish culture is the first examples that came to mind. During these works' restoration and conservation processes, the conservator needs to know lots of things like techniques of ornamental elements nowadays, materials, the topic of workmanship, specialty of traditional handicrafts and features of motives. There needs to be an interdisciplinary coordination accompanied by various departments during the work's documentation and intervention stages. In order to accurately determine the work's current state, the material, technical features, deterioration identification, purpose of use, exhibition and storage terms, it is necessary to work with experts.

Among various historical artifacts that form cultural inheritance, it is possible to see wood materials. Alongside its utility and ease of operation, wood's natural beauty and sustainability -the possibility of growing a new one after cutting down a tree constitutes wood as a replaceable material- are also factors for its favorability. In wood works, the ones exhibited in museums are considered portable but the others with structural dimensions belong the importable group. Wood works have a large area of usage from houses that people use for sheltering to daily used manual devices, musical instruments and fire arms.

This article contains a general knowledge about portable and importable works, supported with photographs of exemplary artworks. Among various historical artifacts that form our cultural inheritance, it is possible to see wood materials. Alongside its utility and ease of operation, wood's natural beauty and sustainability -the possibility of growing a new one after cutting down a tree constitutes wood as a replaceable material- are also factors for its favorability. In wood works, the ones exhibited in museums are considered portable but the others with structural dimensions belong the importable group. Wood works have a large area of usage from houses that people use for sheltering to daily used manual devices, musical instruments and fire arms.

This article contains a general knowledge about portable and importable works, supported with photographs of exemplary artworks. 


\section{GíRiş}

Kültürel mirası oluşturan tarihi eserlerin çoğunda ahşap malzemeyi görmek mümkündür. Ahşabın sadece kullanılabilirliği ve çalışma kolaylığı değil, aynı zamanda doğal güzelliği de onun tercih edilmesinde etken olmuştur. Ayrıca, ahşabın sürdürülebilirlik özelliğine sahip olması da tercih edilmesine neden olmuştur. Yani bir ağaç kesildikten sonra, yerine geçecek bir başka ağacın büyüme imkanının olması, sürdürülebilir, yerine konulabilir olarak tanımlanmasını sağlamaktadır.

Ahşap eserlerin müzelerde sergilenebilir olanları taşınır, ancak yapısal boyutta olan kısımları ise taşınmaz eserler grubundadır. Ahşap eserler, insanların barınma ihtiyaçlarını sağladığı evlerden, gündelik hayatlarını kolaylaştıran el aletlerinde, müzik aletlerinden, ateşli silahlara kadar çok geniş bir kullanım alanına sahiptirler.

Bu çalışma, ahşap eserlerin karşılaşılabilecek mevcut formlarını belirlemek için hazırlanmıştır. Araştırma ile ahşap eserlerin taşınır ve taşınmaz olarak ayrımı yapılmışıı. Bu ayrım sayesinde ahşabın bozulmasına yol açan etkenlerden, restorasyon işlem farklılıklarına kadar ön bilgi oluşturacak ve uygulamacıya yol gösterecektir. Örneğin taşınmaz ahşap eser denildiğinde, eserin dış ortam koşullarına daha fazla maruz kaldığ 1 ve bu sebepten buna uygun tanı, tedavi ve koruma gerektirdiği, taşınır ahşap eser denildiğinde ise (nadir durumlar hariç, örneğin batıklar ya da gömüler) eserlerin genellikle iç mekanda bulunduğu için mevcut duruma uygun uygulamaya gidilmesi gerektiği anlaşılacaktır.

$\mathrm{Bu}$ çalışma taşınır ve taşınmaz eser grupları hakkında genel bilgi ve örnek eser fotoğrafları ile desteklenerek sunulmuştur. Ahşap eserlerin gruplandırılmasına yönelik ulusal literatür içinde bu kapsamda bir ilk çalışma özelliği taşımaktadır.

\section{Ahşabın Kullanım Alanlarının Sınıflandırılması}

Arkeolojik ve etnografik eser olarak ahşap malzeme kullanımının çeşitli sınıflandırılmalarını yapmak mümkündür. $\mathrm{Bu}$ sınıflandırmaları taşınır ve taşınmaz eserler olarak gruplandırarak, kendi arasında da birden fazla alt dallara ayrılabilmek mümkündür. Bu ayrımı yaparken dikkate alınması gereken esaslar bulunmaktadır. Taşınmaz bir eserin durumu in-situ sergilemeye uygun olabileceği gibi, mevcut durumu onu müzede sergilenmesini gerektiriyor da olabilir. Örneğin bir yapının ahşap kapı, pencere ya da süsleme elemanlarından herhangi birinin, in-situ sergilenmesi mümkün değildir ve bu elemanların müzede sergilenmesi gerekmektedir.

Müzelerde sergilenebilecek tamamı ahşap ve kompozit yapıdaki ahşap eserleri; National Park Service [NPS], The Museum Handbook'da şu şekilde belirtmiştir;

- Günlük hayatı kolaylaştırıcı objeler (çiftlik araçları ve aletleri gibi),

- Dini objeler (altar, sunak gibi),

- Dekoratif gerekçe veya tarihi öneminden kaynaklı mobilyalar,

- Baskı, belge ve resim içeren çerçeveler,

- Müzik enstrümanları,

- Dikiş makineleri ve kameralar gibi makineler.

Bu sıralamaya göre taşınır ve taşınmaz ahşap eserler aşağıda bulunan grafiğe göre sınıflandırılmıştır. 


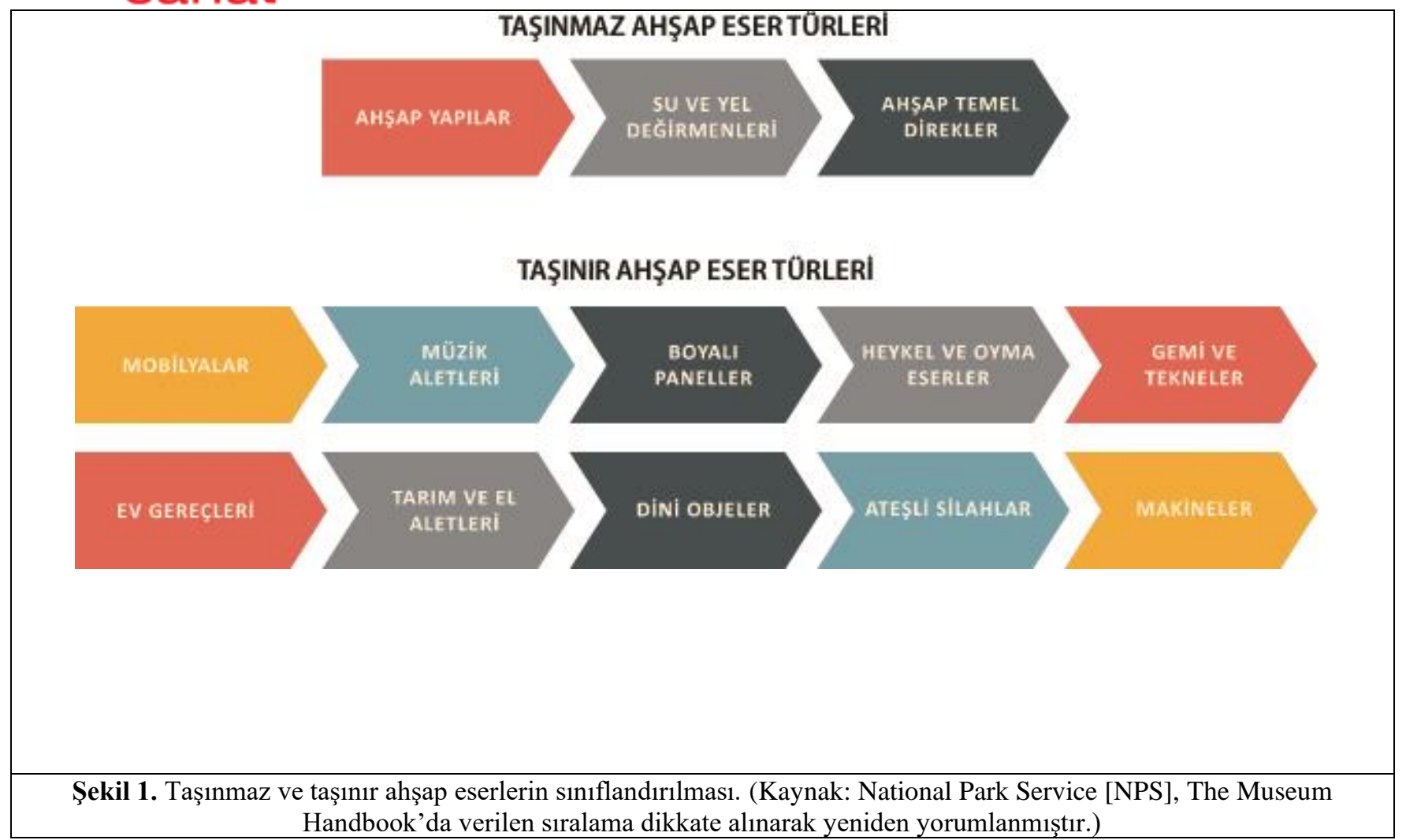

\subsection{Ahşap Yapılar}

Tarih öncesi çağlarda avcı/toplayıcı yaşantı süren insanın, barınma isteği ile birlikte yapılașma sürecinin başladığı söylenebilir. Gerek göçebeliğin sürdüğü bu dönemlerde gerekse çiftçiliğin ve hayvancıllğın neden olduğu yerleșik düzende, öncelikle ev ve anıt mezar işlevli yapılar söz konusudur. Bazen mağara gibi doğadaki mevcut mekanlar; bazen de kamış, saz, çalı, sırıktan, üstü çamurlu çim ya da tezekle sıvanarak yapılmış çatma kulübeler; deri veya yünlü kumaştan yapılan çadırlar ev olarak kullanılmıştır. Bu biçimde yapılan ev tiplerinin yanında anı/anıt mezarlarda büyük boyutlu taşlar yapının esasını oluşturmaktadır (Alioğlu, 1991, s. 3).

Geleneksel yapılar malzemelerine göre, kagir ve ahşap yapılar başlığı altında incelenebilir. Ahşap yapı sistemleri, ağaç gövde tabakalarının üst üste getirilmesi ile oluşturulan yapı sistemidir. Ormanı bol yörelerde yapı malzemesi olarak ahşap seçilir. Kolay işlenebilmesi, depreme dayanıklı olması, yapının kısa sürede bitirilebilmesi yapı malzemesi olarak kullanımını teşvik etmektedir (Alioğlu, 1991, s. 4).

Ahşap, doğada kolaylıkla bulunabilmesi ve kolay işlenilebilen bir malzeme olması sayesinde, mimari yapı elemanlarında özellikle de kapı ve pencerelerde yüzyıllar boyu kullanılmıştır. Beton, demir ve çelik kullanımına göre de kullanımı çok daha eski tarihlere dayanmaktadır.

Yapısal ahşaplar, tarihi binalar, camiler, kiliseler, mezarlar gibi birçok alanda görülmektedir. Örneğin; Ankara'nın Polatlı ilçesinde Frig dönemine ait Gordion arkeolojik alanında 125 civarında tümülüs bulunmaktadır. Dışarıdan bakıldığında bir tepeyi andıran bu anıt mezarların yapımı, büyük bir iş gücü gerektirmiş olmalıdır. Anadolu'nun en büyük ikinci tümülüsü; 300 metrelik çap1, 53 metrelik yüksekliğiyle "Midas Tümülüsü"dür (Fotoğraf 1a). Mezar odasında, çam, sedir ve ardıç olmak üzere 3 farklı ağaç kullanılmıştır. (Kaynak: URL 1) (Fotoğraf 1a). Tamamı ahşap geçme tekniği ile yapılmış ve alizarin türü pigment içeren kalemişlerinin bulunduğu Samsun Bekdemir Camisi de bu sınıflandırmaya örnek olarak verilebilecek yakın dönem eserlerindendir. (Fotoğraf 1b).

Korumanın ana amacı tarihi dokunun özgünlüğünü sürdürmektir. $\mathrm{Bu}$, tarih boyunca yapılan değişikliklere saygı göstererek, onun biçimini, malzemelerini, birleşim özelliklerini, bütünlüğünü, mimari ve kültürel miras değerlerini korumayı kapsar. Bunu yapabilmek için, yapının karakterini tanımlayan tüm özelliklerin olabildiğince korunması gerekir. Karakteri tanımlayan özellikler aşağıdakilerden biri veya birkaçı olabilir:

a. genel taşıııcı düzen,

b. cepheler, ara bölmeler, merdivenler gibi taşıyıcı olmayan ögeler, 
c. yüzey özellikleri,

d. ahşap öğelerin bezenişi,

e. gelenekler ve teknikler,

f. nitelik (veya dereceleri) ve ayırıcı özellikleriyle, yapımda kullanılan malzemeler (ICOMOS, 2017, s. 3).

(a)

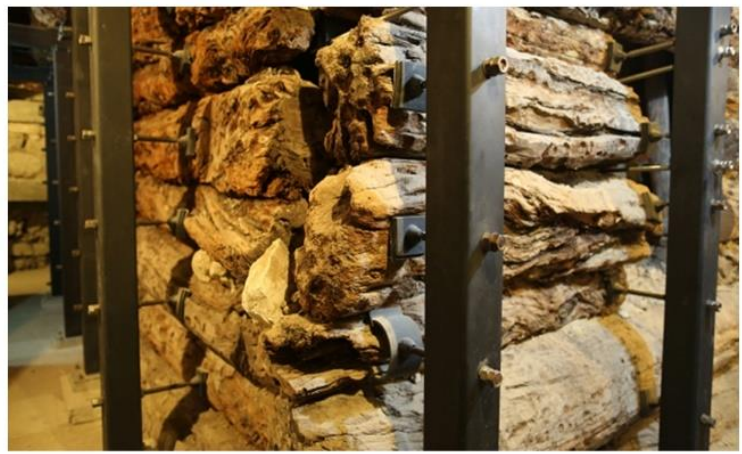

(b)

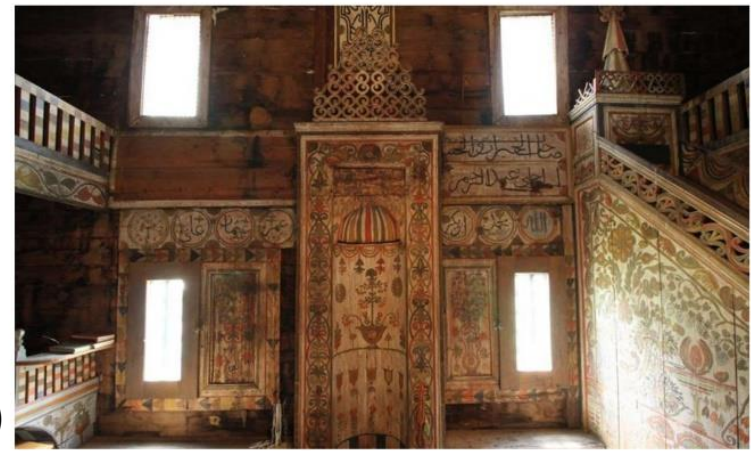

Fotoğraf 1: (a) Kral Midas'ın mezarı olduğu düşünülen Tümülüs (URL 2), (b) Samsun Bekdemir Camii (URL 3).

\subsection{Su ve Yel Değirmenleri}

Geleneksel olarak, su ve yel değirmenlerinin hareketli kısımları ahşaptan yapılmıştır. Su değirmenlerinin makineleri ile yel değirmenlerinin makineleri arasındaki başlıca farklardan biri, su gücünün su değirmeninin en düşük seviyesinde, rüzgar gücünün ise değirmenin en yüksek seviyesinde bulunmasıdır. Hareketli kısımların ahşap malzemeden yapılmasının 3 ana nedeni bulunmaktadır;

1. Demir dişlilerin kullanımından kaynaklanabilecek kıvılcımların tutuşma tehlikesinden kaçınmak,

2. Dişli çarkların ahşap dişlerinin kolayca değiştirilebilir olması,

3. Bir dökme demir çarkın değiştirilmesinin ahşap çarkın değiştirilmesi çok daha ucuz olmasıdır.

Değirmenler yapıldıkları dönem şartları göz önünde bulundurulduğunda bir toplumun yaşam biçimini, üretim tekniklerindeki gelişmeleri ortaya çıkaran tarihi yapılardır. Ahşap bölümlerinde zaman içerisinde oluşan yapısal ve estetik bozulmaları net şekilde ortaya konulmalıdır. Bir yapı tarihi belge niteliğine, tarihi bir olay veya tarihi bir süreci yansitması nedeniyle de sahip olabilmektedir (Ahunbay, 2009, s. 28). İlk çağlardan başlayarak su gücü teknolojisindeki gelişimin izlerini taşıyan, aynı zamanda toplumların kültürel yapısını ve yaşam biçimini yansıtan endüstri mirası örnekleri olan bu yapılar, yapı tipleri, üretim düzenekleri ve üretim teknikleri açısından "tarihi belge" niteliği taşımaktadır (Çorapçıoplu, 2015, s. 233).

Ahşap yapılarda müdahaleler yapının ayakta kalmasını sağlayacak en alt düzeyde olmalı, özgünlük ve bütünlügünü mümkün olduğunca korumalı ve işlevini güvenle sürdürebilmesine izin vermelidir. Bununla birlikte, aşağıda belirtilen özel durumlarda, yapının bir kısmının veya tümünün sökülmesi engellenemez:

a. yerinde (in-situ) ve özgün ögelere yapılacak onarımlar kabul edilemeyecek derecede müdahaleler gerektirecekse,

b. yapının deformasyonu taşıyıcı sistemi tekrar normal davranışına döndürmeyi engelleyecek kadar fazlaysa,

c. yapıyı deforme olmuş biçimiyle korumak için uygun olmayan ek işlemler gerekiyorsa (ICOMOS, 2017, s. 4).

1860'lı yıllarda Çırakman köyünde yaşayan Rumlar tarafından yapılan Karadeniz'in taş gövdeli tek tarihi yel değirmeni olma özelliğine sahip olan değirmenin iç mekanizmasında ahşap kullanılmıştır (Resim 2). 


\section{sanat}

(a)

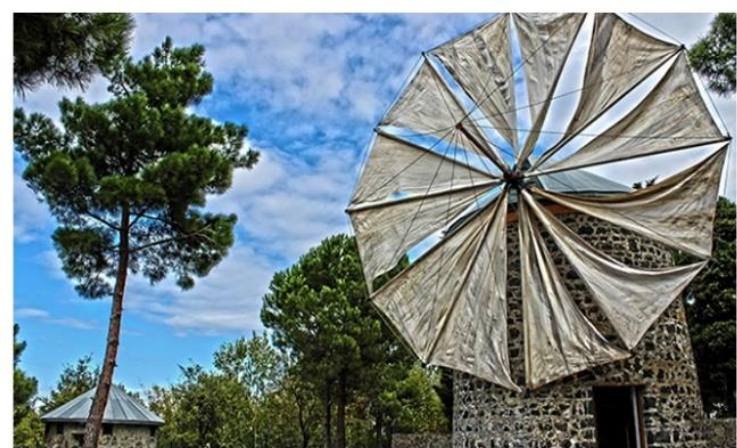

(b)

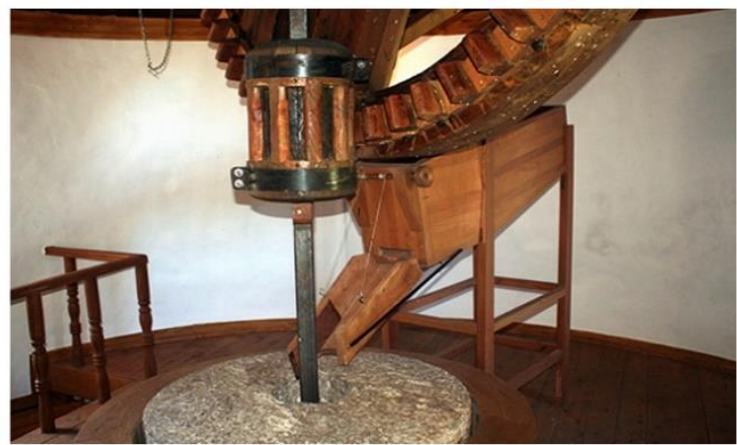

Fotoğraf 2: Samsun Tekkeköy’de bulunan yel değirmeni (URL 4).

\subsection{Ahşap Temel Direkler}

Ahşap yapılarda ana taşıyıcı olarak kullanılan direkleri bu kategoride incelemek mümkündür. Zemini suya veya toprağa temaslı olarak değişebilmektedir. Bir ahşap camide zemini toprağa temas halinde iken, köprü gibi yapılarda ise suya teması mümkündür. Bulunduğu ortam göz önüne alınarak, ahşap türünün seçimi, yapım tekniği, koruyucu malzeme seçimi, süsleme tekniği gibi farklılıklar ortaya çıkmaktadır.

Ahşap, malzeme olarak sahip olduğu avantajlar nedeni ile ilk köprü örneklerinden günümüzdeki modern tasarımlara değin yaygın olarak kullanılmıştır. Ahşabın bu avantajları arasında doğal, yenilenebilir ve sürdürülebilir bir malzeme olması, ağırlı̆̆ına oranla yüksek mukavemete sahip olması, üretimi için düşük enerjinin yeterli olması ile düzenli bakım sonucukolaylıkla daha uzun bir kullanım ömrüne sahip olabilmesi, sayılabilir. Ayrıca, estetik ve güzelliğin ön planda olduğu uygulamalar için de ideal bir malzemedir (Yılmaz vd., 2017, s. 434 ).

Günümüzde büyük açıklıkları geçmede yeni malzemelerin getirdiği yapı sistemlerinin (betonarme, öngerilmeli beton, çelik ve asma sistemler gibi) tercih edilmesine rağmen ahşap, sıcaklığı ve doğallığ 1 nedeni ile belirli açıklıklarda kullanımı süren, giderek daha çok tercih edilir olan bir malzemedir. Endüstriyel olanaklarla dayanıklılığı artırılmış olan ahşap, çağın teknolojik olanaklarının yardımıyla etkin biçimde kullanılmaktadır. (Sütiçen, 2008, s. 20)

A ğaç gövdeleri kullanılarak inşa edilen en eski köprülerden endüstriyel kereste kullanılarak inşa edilen modern örneklere kadar ahşap köprüler; kiriş, konsol, asma, kemer, makas ve kompozit formlarda olmak üzere birçok farklı tipte inşa edilmişlerdir. Ahşap köprüler genellikle yaya, hayvan, bisikletli ve hafif araçlar için inşa edilmiş olsalar da günümüzdeki teknolojik gelişmelerle birlikte artık, nispeten daha büyük yükler için de uygun hale getirilmişlerdir (Y1lmaz vd., 2017, s. 434).

Ahşap köprülerin tarihi ve gelişimi dört döneme ayrılabilir:

1. Orta Çağ öncesi (MS 1000'e kadar),

2. 18. yüzyıldan (1000-1800) Orta Çağ'a kadar,

3. 19. yüzyıl (1800-1900) ve

4. 20. yüzy1l (1900'den günümüze) (Ritter, 1990, s. 1-2)

1875-80 yıllarına tarihlendirilen temeli ve tamamı ahşaptan yapılan tarihi Ordu Başkotanı Deretam Köprüsü günümüze kadar varlığını sürdürmüş ve halen ulaşımda kullanılmaktadır (Fotoğraf 3a,b). 


\section{sanat}

(a)

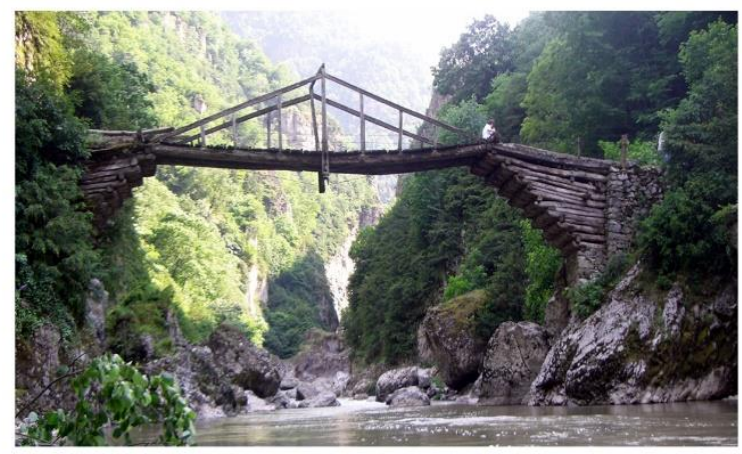

(b)

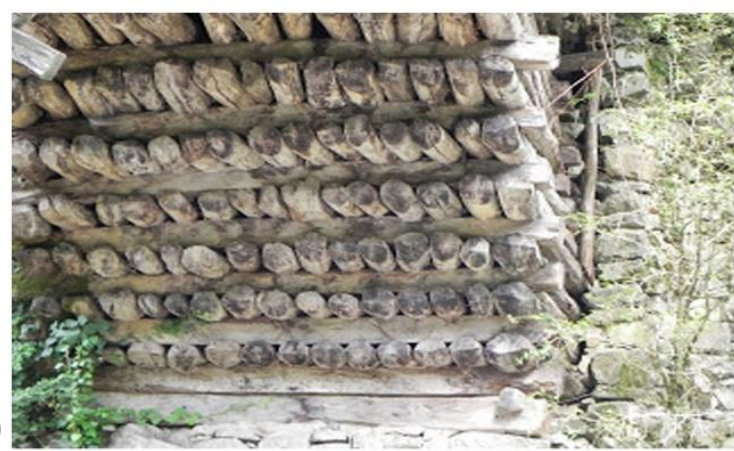

Fotoğraf 3: Başkotanı Deretam Köprüsü. a) Genel (URL 5) ve b) detay görünümü (URL 6).

\subsection{Mobilyalar}

Mobilya sanat tarihi ile ilgili yapılan araştırmalar ve ortaya konan eserlerde genel olarak, mobilya sanatının ilk dönemleri ilk çağ mobilya (Antik dönem) sanatı olarak görülmektedir. Antik dönem MÖ 3000 ile 500 yılları arasını kapsayan dönemdir. Bu dönemde mobilya sanat tarihi bakımından 5'e ayrılmıştır. Bunlar; Mısır, Mezopotamya, Anadolu, Yunan ve Roma mobilya sanatıdır. Genel olarak, ilk ahşap mobilya örneklerine Mısır döneminde rastlandığı bazı kaynaklarda belirtilmektedir (Bal ve Kılavuz, 2015, s. 59).

Mobilya yapımında kullanılan ahşap, görünüşü çok daha önemli olduğu için yapılarda kullanılan ahşaptan çok daha farklıdır. Yapılarda kullanılan kerestelerin bazılarında boyuna çatlaklar genel olarak kabul edilebilirken, mobilyada görsellik daha önemli olduğu için bu durum kabul edilemez bir niteliktir. Ahşap, ucuzluğu, çalışma kolaylığı, hafifliği ve nihai halinde estetik görünümü nedeniyle geleneksel olarak mobilya yapımı için kullanılır. Bu gruba sandıklar, beşikler, gümüşlükler, kavukluklar, sehpalar gibi tüm mobilya grubu eşyalarını almak mümkündür.

Mobilya üretiminde genellikle masif ağaç malzemede:

1. Renk ve doku bakımından üstünlük,

2. Kolay işlenmesi ve düzgün yüzey vermesi,

3. Üst yüzey işlemlerine uygun olması,

4. Budaksız ve düzgün lifli olması,

5. İklim koşullarına dayanıklı, daralma ve genişleme yüzdelerinin düşük olması gibi özellikler aranmaktadır (Kurtoğlu, 1984, s. 87).

Aşağıdaki örneklerde, Gordion kazılarından bulunan ve yeniden yapım (rekonstrüksiyon) tekniği uygulanan kakma ahşap sehpa. (Fotoğraf 4a) ve Sultan I. Ahmed'in ceviz üzerine bağa ve sedef kakma tahtı (Fotoğraf 4b) bulunmaktadır.

(a)

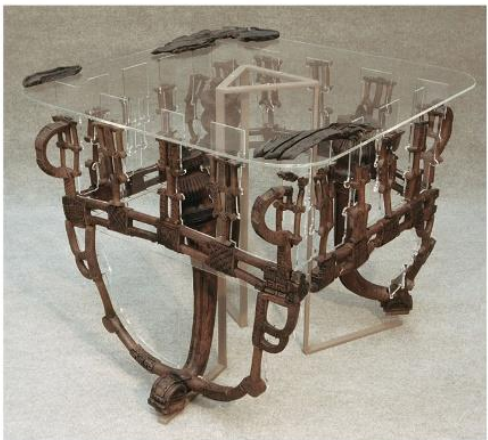

(b)

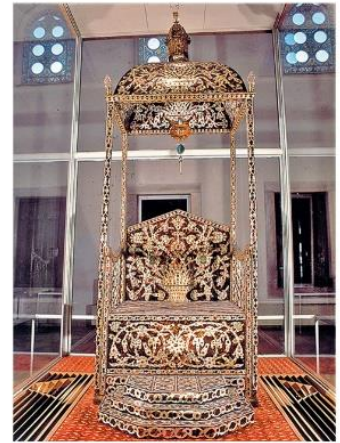

Fotoğraf 4: (a) Gordion kazılarından bulunan kakma ahșap sehpa (URL 7). (b) Sultan I. Ahmed'in kakma tahtı (URL 8). 


\subsection{Müzik Aletleri}

Arkeolojik ve tarihi birçok müzik aletinin hammaddesi olarak ahşap kullanılmıştır. Ancak, müzik aletlerinin akustik gereksinimleri olan belirli parçaları mekanik özelliklere ihtiyaç duymaktadır. Bu yüzden müzik aletleri çoğunlukla kompozit yapı olarak karşımıza çıkmaktadır.

Özellikle yaylı ve mızraplı sazların (keman, viyolonsel, gitar, mandolin v.b.) ses tablası iğne yapraklı ağaçlardan, alt tabla, yanlıklar ve sap kısımları ise yapraklı ağaçlardan yapılmaktadır (ÖNAL S, 176). İğne yapraklı ağaçların; lif uzunluklarının geniş yapraklı ağaçlara göre daha fazla olması, yıllık halkalarının ince ve belirgin olması, yaz odunu oranlarının düşüklüğü ve hafif olmaları müzik aletleri yapımında tercih edilmesine etkenlerdendir.

Çalgıların ses tablasında özellikle ladin (Picea Orientalis), köknar (Abies spp.) tercih edilmiş, bu ağaçlar dışında ceviz (Juglans regia L.), çınar (Platanus sp.) maun (Entandrophragma) sedir (Cedrus libani A. Rich) ve servi (cupressus sempervines L.), ağaçları kullanılmaktadır. Alt tablasında akçaağaç (kelebek) (Acer), ahlat (Pyrus elaeagnifolia Pall.), ıhlamur (Tilia grandifolia Ehrh.), kızılağaç (Alnus), gövdesinde abanoz (Diospyrus ebenum), akçaağaç, akgürgen (Carpinus betulus L.), ardıç (Juniperus sp.), armut (Pirus communis L.), boylu ardıç (Juniperus excelsa Bieb), ceviz, dut (Morus alba L.), elma (Pirus malus L.), erik (Prunus domestica L.), gül, iğde (Elaeagnus Pungens ), kavak (Populus sp.), kızılağaç, köknar (Abies spp.), kuş üvezi (sorbus acuparia L.), ladin, maun, meneviş (Pistacia terebinthus), pelesenk (Guajacum officinale L.), sedir, servi, şimşir (Buxus sempervicens), dilimli teknelerde açık renk elde etmek amacıyla akçaağaç, anini gray (aningeria spp.), ardıç, armut, ayos (Triplochiton scleroxylon), çınar, dişbudak (Fraxinus exelsior L.), dut, elma, etimoe (Copaifera salikounda), thlamur, karaağaç (Ulmus sp.), karadut (Morus nigra), kavak, kestane (Castanea sativa), kiraz, köknar, meranti (Shorea spp.), mürver (Sambucus), niove (Staudtia stipilata), okaliptus (Eucalyptus rostrata), porsuk (Taxus baccata L.), sapele(pomelli) (Entandrophragma cylindricum), sedir, şeftali ( Prunus persica ), tik (Tectonagrandis), turunç (Citrus aurantium) ve koyu renk elde etmek amaciyla ahlat, abanoz, boylu ardiç, coccobolo, (Dalbergia retusa), purple heart (Peltogyne venosa), ceviz, erik, gül,keçiboynuzu (harnup) (Ceratonia ciliqua L.), maun, magase, paduk (Doğu Hindistan Gülü)(Pterocarpus soyauxii), paorosa, (Swartzia fistuloides) pelesenk, sipo (Entandrophragma utile), tiama (Entandrophragma angolense), vengi (Millettia laurentii), vobinga (siyam gülü), yabani kiraz (Prunus avium L.), yılan ağacı (Piratinera guianensis) kullanılmaktadır (Tetik Işık ve Uslu, 2012, s. 26-27).

Çalgıların tuşesinde abanoz, gül, gürgen (Fagus orientalis Lipsky), meşe (Quercus cerris), pelesenk, vengi, sapında akçaağaç, akgürgen, ahlat, elma, erik, gül, gürgen, kiraz, vengi, tel takacağında abanoz, akgürgen, badem (Prunus amygdalus), gül, kayısı (Prunus armeniaca ) ve şimşir, burguluğunda akçaağaç, elma, erik, kiraz, ıhlamur, gürgen, ceviz, burgularında şimşir, ceviz, kayısı, erik, akgürgen, limon (Citrus aurantifolia) eşiğinde abanoz, ahlat, akçaağaç, ardıç, gül, meşe, paduk, paorosa, pelesenk, yayında akgürgen, gül, pelesenk, pernambuk (Guilandina echinata) ve tik (Tectona grandis) ağaçları kullanılmaktadır (Tetik Işık vd., 2012, s. 27).

Aşağıdaki fotoğrafta 1929 'da Leonard Woolley önderliğinde bir arkeolog ekibi tarafından Irak'ta bir kraliyet mezarlığında bulunan ve bugüne kadar ortaya çıkarılan en eski telli çalgı aleti olan "Quenn's Lyre (Kraliçenin Liri) gösterilmiştir (Fotoğraf 5a). Diğer fotoğrafta ise; Christian Kintzing'e atfedilen Alman yapımı, 1707-1804 yıllarına tarihlendirilen, abanoz ve ceviz ahşap ile kemik, boyama, metal işçiliğinden oluşan klavsen bulunmaktadır (Fotoğraf $5 b)$.

(a)

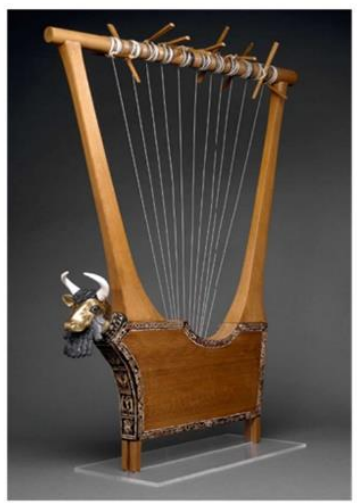

(b)

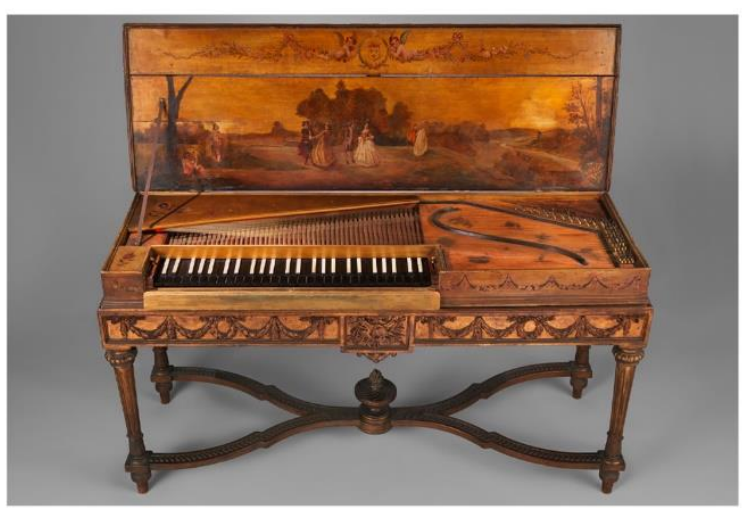

Fotoğraf 5: (a) "Queen'sLyre”, Woolley’nin keşif kayıtlarında yayımlanan Kraliçenin Liri (URL 9). (b) Christian Kintzing'e atfedilen klavsen (URL 10). 


\subsection{Boyalı Panolar}

Ahşap malzeme üzerine kimi durumda doğrudan boyar madde ile kimi zaman zemin malzemesine yapılan tüm boyama işlemlerini bu grupta toplamak mümkündür. Anadolu' da ise ahşap zemin üzerine boyama tekniğinin en güzel örnekleri kalemişlerinde ve edirnekari işlerinde görülebilir. Ahşap paneller üzerine yapılan boyama türlerinin örneklerini de ikonalarda görmek mümkündür.

Ahşap yüzeyler üzerindeki kalem işlerinin ömrü ahşap kadar uzun olabilir. Burada, boyalarda dökülmeler, ağacın içine işleyen izleri ortadan kaldırmamakta, böylece hiç değise bir fikir verecek kadarı kalmaktadır (Demiriz, 1989, s. 315).

Ahşap malzemeye kalemişi süslemelerin yapımında ilk önce, ahşabın üzerine kaynamış bezir yağı (Osmanlı beziri), İngiliz beziri, üstübeç (istidaç) ve bir miktar murdesenk karışımı ile hazırlanan macun sürülerek ahşabın yüzeyi düzgün hale getirilir ve istenilen motif boyanır. Desenler önceden kâğıt üzerine çizildikten sonra bu çizgiler delinerek kömür tozuyla silkeleme tabir edilen metod ile zemine geçirilir. Boya olarak da Arap zamkı bağlayıcı ile toprak boyalar kullanılır. Ahşap üzerine yapılan kalem işleri üç şekilde yapılır:

1. Zemin ince çıtalarla, çeşitli geometrik şekillere bölünür. Buralarda oluşan boşluklara motifler boyanır.

2. Doğrudan doğruya ahşap üzerine yapılan kalem işleri.

3. Kündekâri tekniğiyle yapılan tavanların, renkli boyalarla boyanmasıyla oluşan kalem işleri (Bülbül, 2008, s. 132).

Kutsal kişilerin imgeleri olan ikonalar, MS 3. yüzyıldan itibaren Bizans Hıristiyan Kilisesi'nin önemli bir parçası haline gelmiştir. Kiliselerde, halka açık yerlerde ve evlerde genellikle koruyucu özelliklere sahip olduklarına inaniliyordu (Cartwright, 2017).

Fayum Mumyaları (Fayum Mummy) olarak adlandırılan ahşap sandukalar, meşe, 1hlamur, çınar, sedir, selvi, incir gibi ağaçların üzerine yapılan portreler bu gruba verilebilecek en güzel örneklerdir (Fotoğraf 6a). Burdur, Dengere Köyü Camisi'nin ahşap üzerine kalemişi bezemeleri de ülkemizde görülebilecek ahşap üzeri boyama tekniği örneklerindendir (Fotoğraf 6b).

(a)

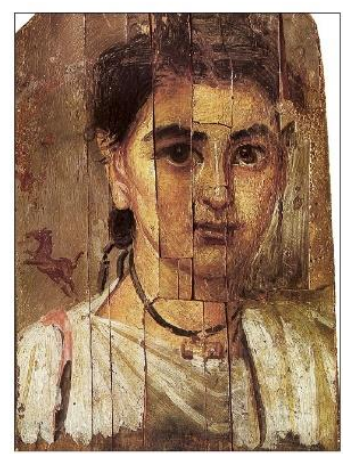

(b)

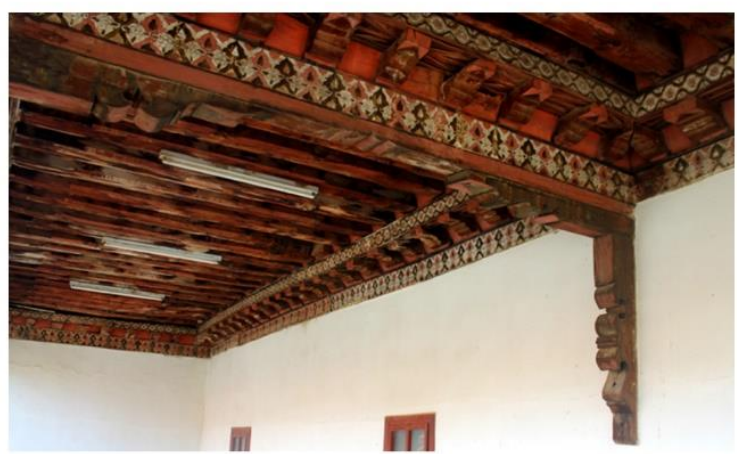

Fotoğraf 6: (a) M.S. 2. Yüzyıla ait Greko-Romen Çocuk portresi, (URL 11). (b) Burdur, Dengere Köyü Camisi’nin ahşap üzerine kalemişi bezemeleri (Eroğlu, 2012, s. 243).

\subsection{Heykel ve Oyma Eserler}

Ahşap malzemenin üzerine bezeme, desen, figür gibi birçok süsleme tekniğinin kullanılarak yapıldığı ya da tamamen boyutsal figürlerin çalışıldığı eserleri bu gruba almak mümkündür. Anadolu'da İslamiyet'in etkisi ile heykelcilikten daha çok oyma tekniğinin kullanıldığı, minber, kapı, pencere süslemelerinin yapıldığı ahşap eserlere rastlamaktadır. Oyma eserlerde kullanılan teknikler şu şekilde sıralanabilir;

\section{Oyma tekniği}

2. Şebekeli oyma (Ajur) tekniği

3. Geçme tekniği

4. Kakma tekniği (Kerametli, 1962, s. 10-11).

Bu grupta incelenebilecek tekniklerden birisi de kündekari tekniğidir. Bu teknik ile yapılan minber, kapı, sandık gibi eserler görülmektedir. Ayrıca Edirnekari tekniği ile yapılmış, çekmeceler, kavukluklar, sandıkları da bu grubun elemanları arasına almak mümkündür. 
Anadolu Selçuklu ahşap işçiliği kendine has bir üslûp oluşturmuş, bu üslûp ve uygulanan teknikler Beylikler ve kısmen Osmanlı dönemlerinde devam etmiştir. Minber, mihrap, pencere ve kapı kanadı gibi eserlerde daha çok kündekârî ve taklit kündekârî tekniklerinin tercih edilmesi dikkat çeker. Bu tür eserlerde birbirine simetrik geometrik paneller genellikle girift palmet yapraklı arabesk oyma motiflerle doldurulmuştur; bordürlere de buna uygun oyma desenler yahut kûfî veya sülüs yazı şeritleri yerleştirilmiştir. Osmanlılar'da oymacılık sanatı en üst seviyesine ulaşmıştır. İlk büyük merkez olan Bursa'da Yeşil Cami'nin taçkapısı, pencere söve ve alınlıkları, mihrap nişi ve kitâbesi Osmanlı mermer oymacılığının, Ulucami'nin minberi de Osmanlı ahşap oymacılığının Selçuklu üslûbunun devamı niteliğindeki ilk önemli örnekleridir (Bozkurt, 2007, s. 13-15).

Dünyanın en eski bilinen en eski heykeli (11.000 yaşında) Yekaterinburg'a $100 \mathrm{~km}$ mesafede Ural dağ1 eteklerinde ele geçen ahşap Shigir İdolü, insan yaratıcılığının en eski örneklerinden biridir. (Fotoğraf 7a). Ülkemizde kündekari tekniğinde yapılmış birçok eser vardır. Bunlardan Konya, Beyşehir Eşrefoğlu Camisi kündekari tekniği ile yapılmış minberi de bir örnek olarak karşımıza çıkmaktadır (Fotoğraf 7b).

(a)

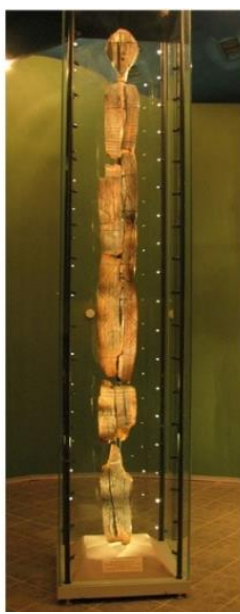

(b)

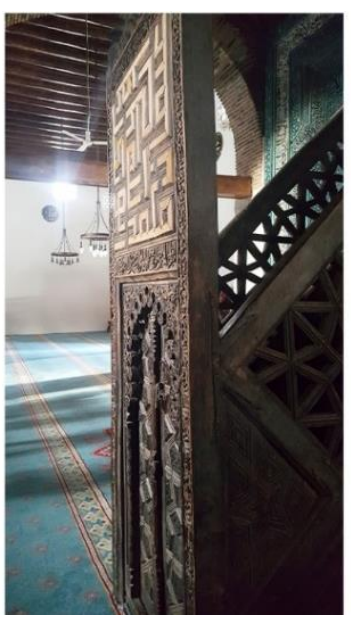

Fotoğraf 7: (a) Shigir İdolü (URL 12). (b) Konya, Beyşehir Eşrefoğlu Camisi minberi (URL 13).

\subsection{Gemi ve Tekneler}

Suya doymuş eski ahşapların korunması, tüm koruma çalışmalarının en karmaşık yöntemleri içeren alanı olduğunu söylemek yanlış olmaz. Çünkü uzun yıllar boyunca suda kalmış ahşap kimyasal olarak tamamen bozulmaya uğramış şekilde karşımıza çıkmaktadır. Yapısal olarak ahşabın kullanıldığı oyma kayık tarzı araçların yanı sıra, metal, deri, gibi kaynaklar ile kompozit yapıda karşımıza çıkabilmektedir. Arkeolojik olarak değerlendirilebilecek tekne/gemi türlerini şu şekilde sıralamak mümkündür;

1. Oyma Kayık,

2. Sal,

3. Deri Tekne,

4. Çömlek Tekne,

5. Kaplama-Önce Yöntemiyle Yapılan Tekneler,

6. İskelet-Önce Yöntemiyle Yapılan Tekneler (URL 14).

Kesin olarak bilinen en eski gemi, firavun Keops'un (M.Ö. 1960-3908) cenaze töreni için yapılmış, mezarının yanındaki bir hendekte kumla kaplanmış olarak bulunan, güvertesiz teknedir. $40 \mathrm{~m}$ uzunluğundaki, en büyüğü $23 \mathrm{~m}$ uzunluğunda 600 ayrı kereste parçasından yapılmış bu teknenin, yalnızca Keops'un cenaze töreni için kullanıldığı, ne denize açıldığı ne de Nil’de yüzdürüldüğü düşünülmektedir (Özdemir, 2015, s. 425).

Gemi yapımında kullanılan ağaç malzeme;

a. geminin yapım aşamasında destek olarak yardımcı malzeme şeklinde, 


\section{sanat}

b. büyük gemilerin yapımında

c. küçük deniz taşıtlarının yapımında kullanılan malzeme olarak üç başlık altında incelenebilir (Bülbül, Filik, 2019, s. 3).

Antik dönemde insanoğlu ahşabın bol bulunduğu ortamlarda kayıkları ağaç kabuklarından inşa edilmiştir. Bu kabuk kanolar aletsiz yapılabildiği için belkide tasarlanan en eski tekneler bile olabilir. Kütükten yapılmış kayıklar Taş Çağının başlangıcından Antik Çağın sonuna kadar, coğrafi olarak ise İspanya'dan Hindistan'a kronolojik olarak gelişim göstermiştir. Guadalquiver, Rhone, Elbe, Tuna, Nil, Phasis, Fırat; İspanya, Almanya, Doğu Akdeniz, Karadeniz, Doğu Afrika, Hindistan kıyıları boyunca bulunan ormanlık alanlar bu kütükleri temin edebilecekleri yerlerdir (Casson, 1971, s. 7-8).

Osmanlı'da Tersane-i Âmire'de kereste temini ve tedariki en önemli husustur. Bu amaçla keresteler "Ocaklık Kereste" ve "Ocaklık Harici Satın Alınan Kereste" yoluyla iki yoldan temin edilmiştir. Gemi inşasında en çok tercih edilen kereste çeşitleri; meşe, çam, karaağaç, kestane, ceviz, şimşir, ıhlamur ve çınardır. Keresteler, genellikle gemilerin inşasında kullanıldıkları yere göre "bodostama-i kadırga, eygü-i paşa, kemere-i kadırga", ağacın adına göre "çam, bellût, vürdinar-1 çam" veya ait oldukları bölgenin adına göre "Rumeli-i kebîr, taban-1 Şile, elvâh-1 İznikmid" olarak anılmışlardır (Beydiz, 2017, s. 2).

Sualtı çalışmalarla ele geçirilen dünyanın bilinen en eski teknesi "Pesse kano" (Fotoğraf 8a) ve ülkemizde derin araştırmaları yapılan "Yenikapı Batıkları"nda ele geçirilen eserler bu gruptandır (Fotoğraf 8b).

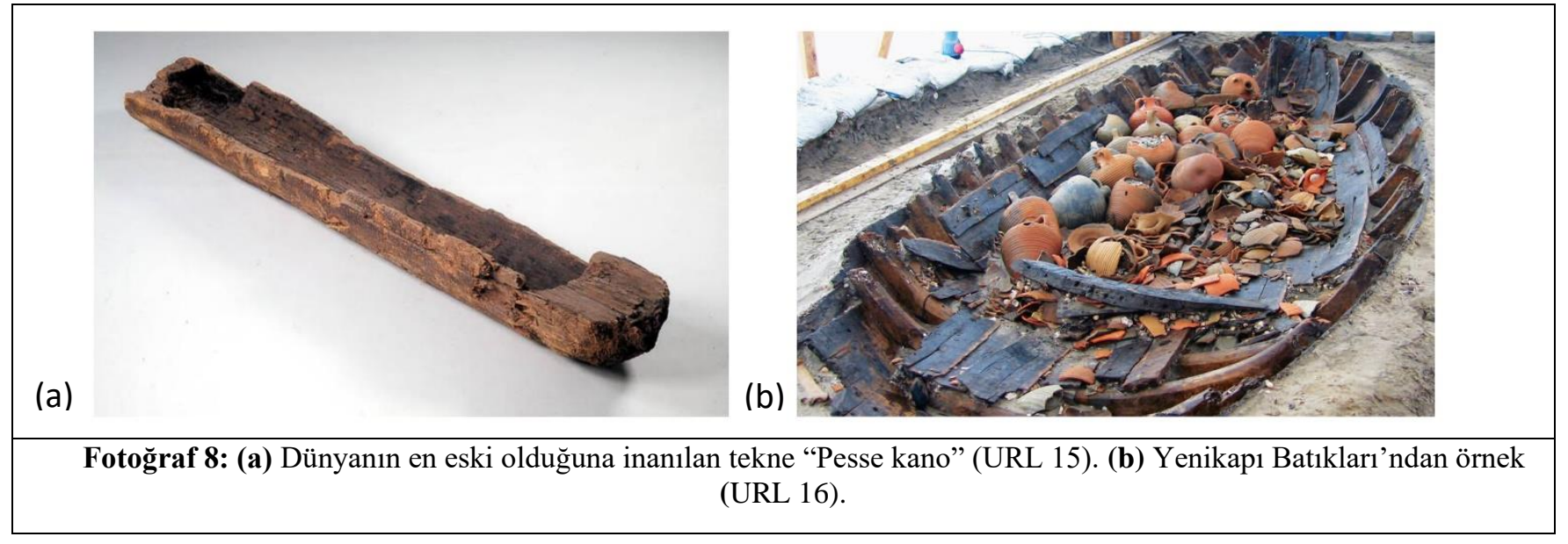

\subsection{Ev Gereçleri}

$\mathrm{Bu}$ kısımda incelenebilecek objelere, yeme-içme gereçleri ve oyuncaklar gibi gündelik hayatta kullanılan eşya grubuna sınıflandırmak mümkündür. Bu gruba, mekanik aksamın da dahil olduğu daha karmaşık yapıda olan ve metal, altın, sedef kaplama gibi özellikleri de üzerinde bulundurabilecek saatleri de eklemek mümkündür. Oyuncaklar açısından Anadolu'nun bilinen en eski buluntusu, Mardin'in Kızıltepe ilçesinde yüzey araştırması yapan arkeologlar tarafından bulunan ve halen Mardin Müzesi’nde sergilenen Kalkolitik Çağ’a (Bakır Taş Çağı, MÖ 4.500 - 3.300) tarihlenen pişmiş topraktan yapılmış bir araba modelidir. Tekerlekleri ahşap bir çubukla gövdeye bağlanan bu araba, "Anadolu'nun bilinen en eski oyuncak arabası" olarak kabul edilmektedir. Frig dönemine ait olduğu belirlenen ve Gordion' da bulunan tümülüsün mezar armağanları arasında ahşaptan yapılmış dokuz küçük hayvan, iki aslan, dövüş halinde bir aslan ve bir boğa, balık yiyen bir grifon, iki boğa, bir öküz, boynuzlu bir geyik, sıçrayan bir keçi, tüyleri özenle işlenmiş bir kuş, iki şahin bulunan şimşir ağacından yapılmış minyatür heykeller mezarın kraliyet mensubuna ait oyuncaklarıdır (Begiç, 2017, s. 19).

Aşağıdaki örneklerde; yapımı 19. yüzyılın ortalarına denk geldiği düşünülen ahşap ve metalden yapılmış mekanik oyuncak atlıkarınca (Fotoğraf 9a) ve 1678-1733 yılları arasına tarihlendirilmiş ceviz ve meşe ağacından üretilmiş ahşap saat bulunmaktadır (Fotoğraf 9b). 
(a)

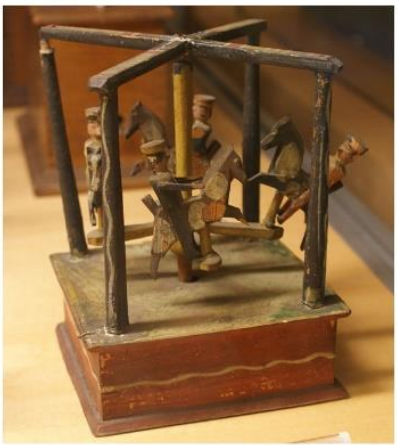

(b)

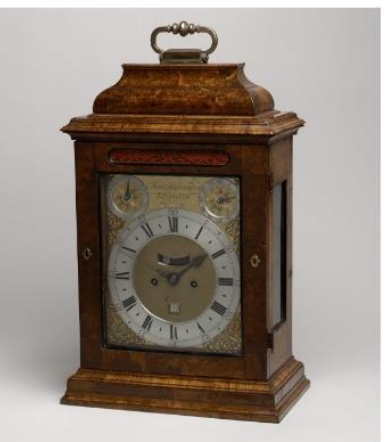

Fotoğraf 9: (a) Ahşap ve metalden yapılmış mekanik oyuncak atlıkarınca (URL 17). (b) Ahşap saat (URL 18).

\subsection{Tarım ve EI Aletleri}

Buğdayı evcilleştirme başarısı, insanları Dicle ve Fırat ırmakları ile kolları arasındaki sulak alanlarda yeni yerler araştırmaya yönlendirmiş ve bunun sonucunda, Mezopotamya' da tarıma dayalı ilk yerleşmeler ortaya çıkmıştır. İlk tarım deneyimi, olasılıkla önceleri tohumların doğrudan toprağa atılması şeklinde yapılmışken, daha sonraları çift sürme olarak adlandırdığımız, insan kuvvetiyle sürülen toprağa tohumların atılma şekline dönüştüğü anlaşılıyor. Toprağı sürme işleminde ise muhtemelen ağaç dallarından kestikleri, çekildiğinde toprağı kazıyabilen "V" şeklini andıran bir aleti yani sabanı kullanmışlardır. Daha önce doğrudan toprağa atılan tohum bire birkaç vermişken, saban sayesinde toprağın sürülmesi ile yaratılan mineral zenginliği eski insan için kayda değer bir verim artışı sağlamıştır. Hayvanların evcilleştirilmesi sürecinde, özellikle boğanın evcilleştirilmesi ve onun gücünden istifade edilerek onu çift sürmede kullanmaları, insanoğlunun uygarlaşma sürecindeki bir diğer önemli atılımı olmuştur (Akın ve Esgici, 2015, 34).

Ahşap tarım ve el aletleri, tamamı ahşap ya da metal, kemik gibi materyaller ile birlikte kompozit yapıda da karşımıza çıkmaktadır. Arkeolojik veya etnografik tarım aletlerinde insan ya da hayvan kas gücünün kullanıldığı eserler öne çıkmaktadır. İnsanların temel ihtiyaçlarından olan yiyeceğin miktarını artırmak için ve bunu yaparken de daha az beden gücü harcama isteği tarım aletlerinin gelişmesinde etkili olmuştur. Bu gruba avcılık için kullanılan aletleri almak da bu yüzden mümkündür. Mutfak için gerekli aletlerin yapımında; gürgen, çınar ve akçaağaç türleri tercih edilmektedir.

Aşağıda, Londra'da Doğa Tarihi Müzesi'nde sergilenen porsuk ağacından yapılmış “Clacton Mızrağı” (Fotoğraf 10a) ve 20. yüzyıla ait metal aksamlı ahşap bir tekerlek örnek gösterilmiştir (Fotoğraf 11b).

(a)

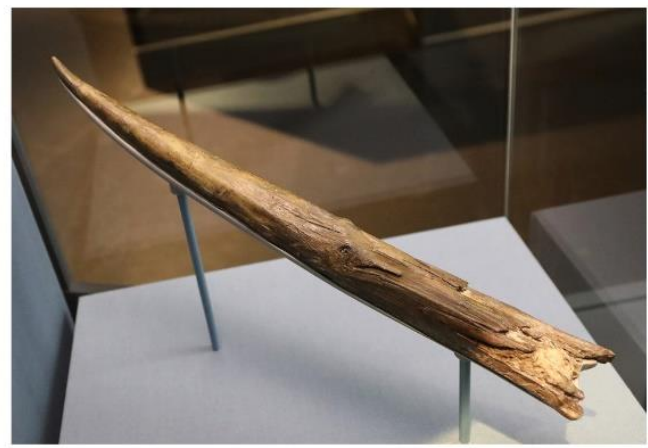

(b)

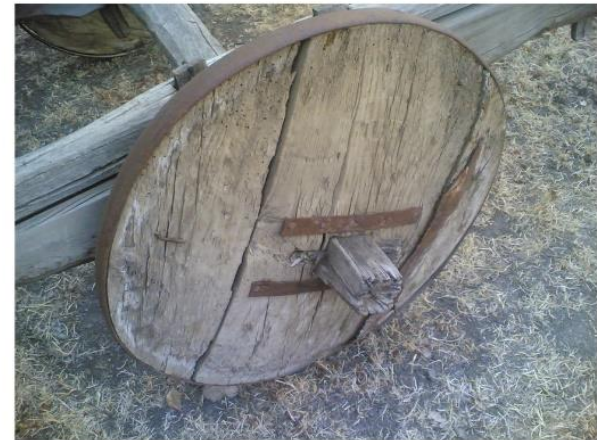

Fotoğraf 10: (a) Clacton Mızrağı (URL 19). (b) 20. Yüzyıla ait metal aksamlı ahşap bir tekerlek (URL 20).

\subsection{Dini Simgeler}

Tarih öncesi çağlarda ayakta kalmaya çalışan ve günlük ihtiyaçlarını karşılama eğiliminde olan insanlığın temel uğraşı avcılık ve tarım olmuştur. Avcılık döneminde göçebe yaşayan insanoğlu tarımla birlikte yerleşik hayata geçmiştir. Bu doğrultuda ortaya çıkan ilk sanat eserleri avcılık ekonomisi ve ürün bereketi ile ilgiliydi. Göçebe yaşanılan dönemde eserler daha işlevsel ve günlük kullanıma yönelik iken insanın yanında taşıyabileceği ağırlıkta materyallerin kullanımı kaçınılmaz olmuştur. Tarım toplumu ile birlikte hasat ve kuraklık kavramı insanın hayatına 
girmiş ve eserler bereket kavramı etrafında yoğunlaşmıştır (Ateşli, 2017, s. 4).

Dini törenlerde, adak törenlerinde ya da ayinlerde kullanılan, insanların dua etmek için kullandığ tüm figür ve objeleri bu grupta değerlendirmek mümkündür. Dini değerlere göre sembollerin esin kaynağ doğa olurken, İslam eserlerinde daha çok bezemeli süslemeler görülmektedir. Törensel ve ritüel nesneler, insanlar arasındaki iletişimi sağlamak veya sürdürmek için bir araç olarak kullanılmıştır. Dini semboller arabuluculuk görevinin yanında, kutsal emanetler olarak da karşımıza çıkmaktadırlar. Bu eserler kutsama, taç giyme veya dua etme amacıyla etme amaçlı kullanılan araçlardır. Sunaklar, ikonalar, rahleler, büstler, tılsımlar, çanlar, sadece dini ritüellerde kullanılan müzik aletleri (şaman davulu gibi), tesbihle ve tabutlar gibi birçok eser bu gruba alınabilir.

Aşağıdaki örneklerde, dini ritüellerde kullanılan 19. ve 20. yüzyıla ait, Nijerya kökenli boyalı ahşap "Yoruba Dans Heykeli (Fotoğraf 11a) ve Mevlana Müzesi 332 envanter numaralı ceviz ağacından yapılmış Selçuklu Dönemi rahle gösterilmiştir (Fotoğraf 11b).

(a)

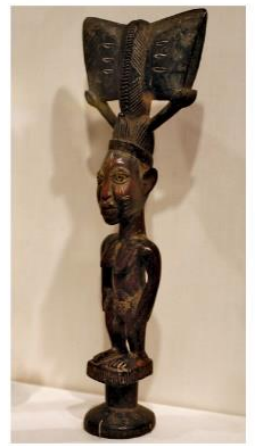

(b)

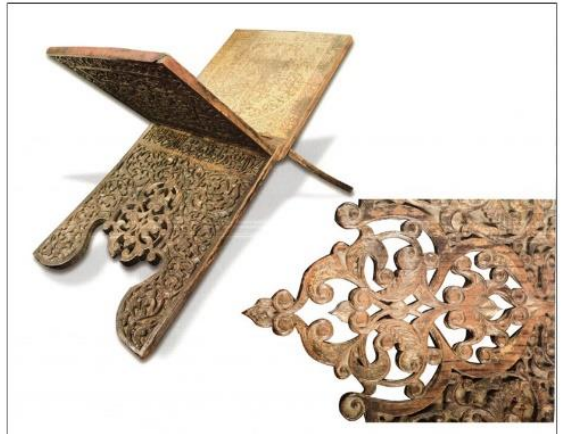

Fotoğraf 11: (a) Yoruba Dans Heykeli (URL 21). (b) Selçuklu Dönemi eseri rahle (URL 22).

\subsection{Ateşli Silahlar}

Ateşli silâhlar 14. yüzyılın ortalarından itibaren Endülüs'te, 14. yüzyılın ilk çeyreğinden itibaren de Avrupa'da kullanılmaya başlanmıştır. Bu tarih aynı zamanda Osmanlı Beyliği'nin kuruluşunun ilk yıllarına rastlamaktadır (Aydüz, 2004, s. 266).

Ateşli silahlar, büyük toplardan tüfeğe, av tüfeğine ve tabancaya kadar her türde ve boyuttaki silahları kapsar. Bu gruptaki eserler, mekanik bir aksama sahip eserlerdir. Genelde ahşap bir kundak üzerinde gümüş, altın gibi metalleri ve oyma, kakma gibi tekniklerle yapılmış süsleme unsurlarını barındırırlar. Ahşap kundak sade olabileceği gibi üzerinde süsleme tekniklerini de bulundurabilir. Aynı şekilde metal aksamlar da ahşap kundaklar gibi sade süsleme teknikleri kullanılarak tamamlanmışlardır. Aşağıdaki örneklerde, Topkapı Sarayı'nda sergilenen, ahşap kundak üzerine yerleştirilmiş namludan ve namludaki ateşleme tertibatıyla nişangâhtan meydana gelen iki tüfeğin süslemeli kabza ve tetik mekanizmaları (Fotoğraf 12a) ve Deniz Müzesi Komutanlığı'nda sergilenen 19. yüzyıla ait ahşap oyma süslemeli çakmaklı tabanca fotoğrafları bulunmaktadır (Fotoğraf 12b).

(a)

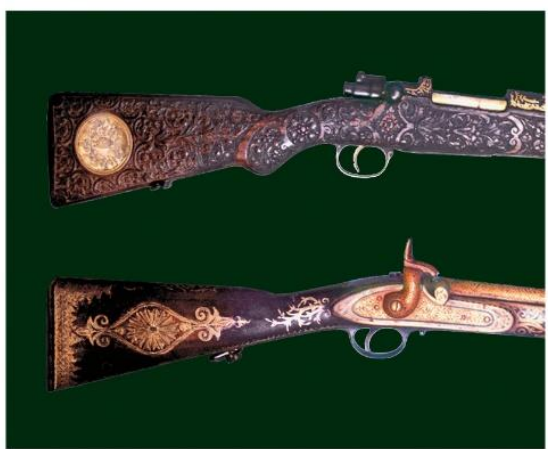

(b)

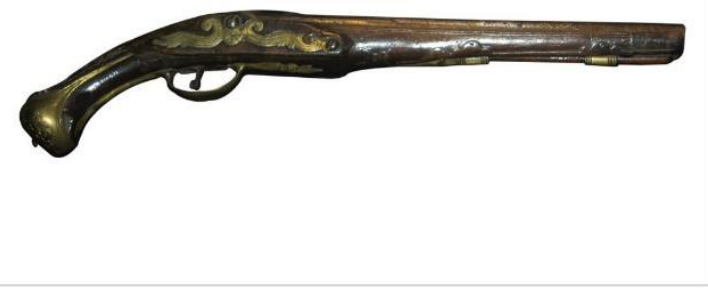

Fotoğraf 12: (a) Topkapı Sarayı'nda sergilenen iki tüfek (URL 23). (b) Deniz Müzesi Komutanlığı'nda sergilenen çakmaklı tabanca (URL 24). 


\subsection{Makineler}

2. Dünya savaşı sırasında, her türlü iklim koşulları ve rutubete dayanıklı yapay reçine tutkalının bulunması ve ahşap yapılarda kullanılması inşaat teknolojisi açısından reform olarak kabul edilmiş ve ahşabı diğer yapı malzemeleri ile yarışır hale getirmiştir (Çalışkan, Meriç ve Yüncüler, 2019, s. 110).

Makinelerde ahşap tercih edilmesinin nedenlerini şu şekilde sıralayabiliriz;

- Birleşimi kolay bir malzeme olan ahşap yapı elemanları, birbirlerine geçmeli bağlanabilir; yapıştırılabilir; çivi, bulon, vida, metal lama yardımı ile birleştirilebilir.

- Birleşim elemanları kolay sökülebilir olduğundan yapının demontajı yapılıp, ahşap malzemeler farklı binaların yapımında tekrar kullanılabilir.

- Is1 yalıtımı yönünden iyi bir malzemedir.

- Kimyasal etkilere ve asitlere karşı dayanıklıdır.

- İşçiliği kolaydır ve şantiye ortamında dahi istenilen şekil verilebilir.

- Kurutulmuş ahşap iyi bir elektrik yalıtkanlığına sahiptir.

- Doğadan kolay bir şekilde elde edilebilir (Çalışkan vd., 2019, s. 114).

Bu gruptaki eserlerde ahşap genel olarak makineyi taşıyan, dış etkenlerden koruyan ya da süsleme nesnesi olarak kullanılmaktadır. Makinenin asıl tutucu kısımları ahşap olabildiği gibi, makinenin belli parçaları da ahşaptan oluşmuş olabilir.

Aşağıdaki örneklerde, 1839 tarihli dünyanın en eski fotoğraf makinelerinden sayılan bir kamera (Fotoğraf 13a) ve ahşap masa üzerinde bir dikiş makinesi fotoğrafı bulunmaktadır (Fotoğraf 13b).

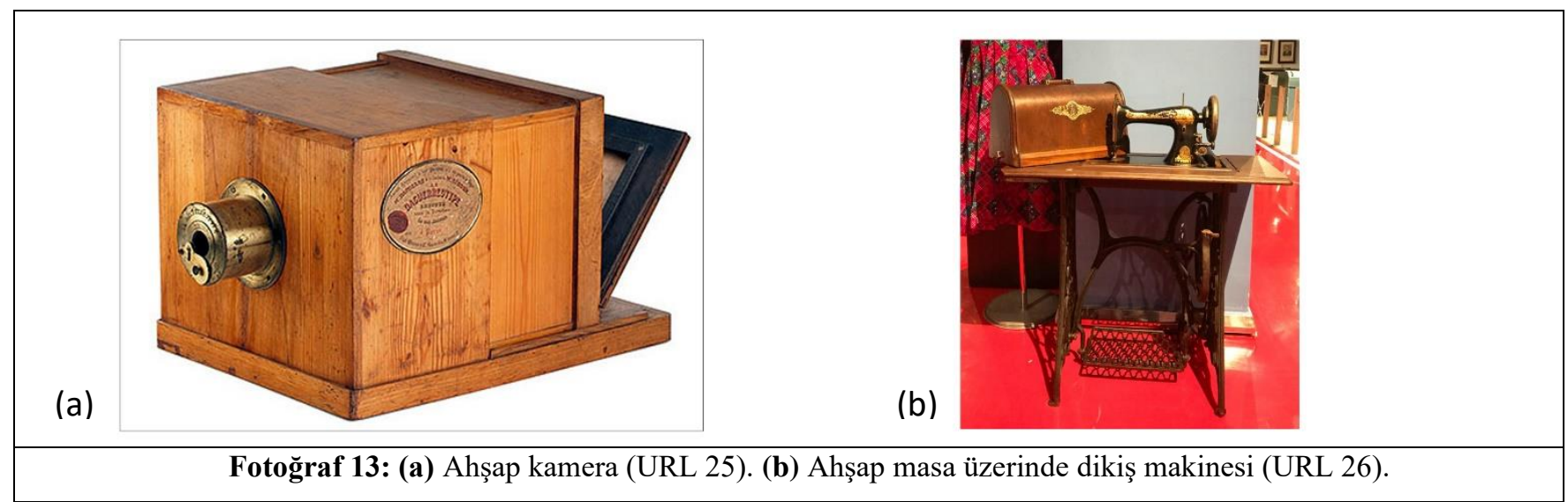

\section{Taşınır Ahşap Eserlerde Kullanılabilir Ağaç Özellikleri ve Türleri}

Ağaç türü taşınır ahşap eserlerin yapımında belirleyicidir. Aynı ağaç türü olsa dahi belli kusurları taşıyan ağaç taşınır eser yapımında tercih sebebi olamaz. Ağacın belirli özelliklerinin oluşmuş olması gerekmektedir. Bu özellikleri şu şekilde sıralanabilir;

1. Ağaç olgun olmalı (50 ya da 100 yaşında, bazen daha da fazla),

2. Kalın ve yuvarlak bir gövdeye sahip olmalı,

3. Yetişmesine uygun çevresel şartlar olmalı (iyi drene edilmiş bir toprakta yetişmeli, büyüme halkalarının simetrisini bozacak veya bükülmesine neden olabilecek rüzgarlı konumda olmamalıdır. Çünkü rüzgara maruz kalan ağaçlarda gövde cılızlığı artmaktadır),

4. Gövde düz olmalı (çünkü bu düz bir lifin işaretidir),

5. Ağaç gövdesinde dallar bulunmamalı ve uzun boylu olmamalı (Bu durum budaksız yapıda bir odun garantisi demektir),

6. Kabuk kısmı sağlıklı ve lekesiz olmalıdır.

Eser yapımı için ahşap seçimi ayrıca sanatkarın kişisel deneyimlerine de bağlıdır. Örneğin; bir enstrüman üreticisi 


\section{sanat}

gövdeye baltasının düzüyle vurur ve ağacın sesini dinler. Bazı ağaçlarda doğal olarak bir ses ahengi bulunmaktadır. $\mathrm{Bu}$ tür ağaçlar net, güçlü ve kalıcı bir nota verirken, diğerleri daha taklit bir nota sesi verir veya ses ilk titreşimde boğulur. Son olarak enstrüman üreticisi, ağacın uygun ses tonunda olduğuna kanaat getirdikten sonra, ağacın sağliklı olmasını, ateş, don çatlak veya mantarlar veya böcekler tarafindan istila izinin bulunmamasını sağlamak için gövdenin kalbine giden bir öz numune çıkarır. Bu titiz denetim ayrıca standartlarına uymayan bir ağacın kesilmesini de önler. Bununla birlikte, ahşabın bir keman, gitar veya klavsen haline getirilmesinden önce yapılması gereken çok fazla işlemin olduğunu da belirtmek gerekir (URL 27).

Ağaçlar, ibreli (iğne yapraklı) ve geniş yapraklı ağaç türleri olmak üzere 2 ana grup altında toplanabilir. Bu türlere örnekler Tablo 2'de belirtilmiştir (Orman Atlası, 2013).

\begin{tabular}{|c|c|}
\hline İbreli (İğne Yapraklı) Ağaç Türleri & Geniş Yapraklı Ağaç Türleri \\
\hline Sarıçam & Meşe \\
\hline Karaçam & Kayin \\
\hline Kızılçam & Gürgen \\
\hline Sedir & Kızılağaç \\
\hline Göknar & Akçaağaç \\
\hline Doğu Ladini & Dişbudak \\
\hline Fistıkçamı & Kestane \\
\hline Ardıç & Çınar \\
\hline Porsuk & Huş \\
\hline Servi & Ihlamur \\
\hline Halepçamı & Siğla \\
\hline Sahilçamı & Kavak \\
\hline P.Radiata & Kayacık \\
\hline Duglaz & Okaliptus \\
\hline Diğer ibreli türler & Findık \\
\hline & Defne \\
\hline & Şimşir \\
\hline & Ceviz \\
\hline & Kermezmeşesi \\
\hline & Maki \\
\hline & Ilgin \\
\hline & Kibris Akasyası \\
\hline & Üvez \\
\hline & Diğer yapraklı türler \\
\hline
\end{tabular}

Genel olarak yapraklı ağaç türlerinin mobilya üretiminde kullanımı, iğne yapraklı ağaç türlerine oranla daha fazladır. Sebebi daha kolay şekil almasıdır. Ülkemizde kaliteli mobilyalarda Karaağaç (Ulmus spp), Meşe (Quercus spp), Ceviz (Juglans nigra) gibi yapraklı ağaç türleri tercih edilmektedir. Genellikle iğne yapraklı ağaç türlerinin yanı sıra bazı yapraklı ağaç türlerinden Kayın (Fagus orientalis), Kavak (Populus spp) astar kaplama olarak daha yaygın olarak kullanım bulmaktadır (Kurtoğlu ve Sofuoğlu, 2013, s. 10).

Yenileme için kullanılacak ahşap tercihan:
a. özgünle aynı cins olmalı,
b. nem oranı özgünle uyumlu olmalı,
c. görünen yerlerde aynı doku özelliğine sahip olmalı,
d. özgünle aynı aletler kullanılarak, benzer yöntemlerle işlenmelidir (ICOMOS, 2017, s. 3).

\section{SONUÇ}

Ahşap eserlerin çeşitliliği, eserin istisnai özellikleri dışında bulunduğu bölgede yetişen ağaç türleri ile de yakından ilişkilidir. Ancak bu durum özel nitelik gerektiren eserler için geçerli değildir. Örneğin bir müzik aleti yapılırken her ağacın kendi akustik tonunu bilmek gibi olgunlaşma süresi gelmiş ağaçların seçimi de önemlidir. Sanatçlar eserlerin kullanım alanlarına göre dayanıklılık, güzel görünüş, hafiflik, akustik, kolay şekil alabilmesi gibi özelliklerine göre ağaç seçimi yapmışlardır. Kullanılan ahşap eserler ham olarak kullanıldığı gibi, süsleme elemanları ya da kompozit bir yapıda kullanılmıştır. Eserin belgelenmesi, bozulma etkenleri hakkında ön bilgi verebilmesi, eserin yapısı hakkında genel bir görüş oluşturulması açısından ahşap eserlerin gruplandırılması önemlidir. Ahşap makineler ya da 
ateşli silahlar kategorisinde kompozit yapıda bir eserin, metal ile etkileşimi sonucu bozulması, ahşap bir heykelde ham ahşap ya da süsleme elemanlarından kaynaklanan bozulmalar, kullanılan boyadan kaynaklanan bozulmalar olabileceği tanısı restorasyon tekniklerinin seçiminde ön bilgi olacağ için restoratörün esere müdahale sürecini hizlandiracaktır.

Ahşap eserlerin restorasyon işlemlerinde in-situ ve özgün ögelere yapılacak onarımlar kabul edilemeyecek derecede müdahaleler gerektirecek, deformasyon normal davranışı engelleyecek kadar fazla ve deforme olan kısımlar ek işlemleri gerektiriyor ise eserin bir kısmının veya tamamının sökülmesi kaçınılmazdır.

Restorasyon işlemlerinden kullanılacak ahşabın özgünle aynı cins olmalı, nem oranı özgünle uyumlu olmalı, görünen yerlerde aynı doku özelliğine sahip olmalı, özgünle aynı aletler kullanılarak, benzer yöntemlerle işlenmelidir. Yenilenen ahşap yapay olarak eskitilmeye çalışılmamalıdır. 


\section{KAYNAKÇA}

Ahunbay, Z. (2009). Tarihi Çevre Koruma ve Restorasyon. İstanbul: YEM Yayın.

Akın, E., Esgici, R. (2015). Eski Çağda Tarım Aletleri, Tarım Makinaları Bilimi Dergisi, 11(1), 33-37.

Alioğlu, F. (1991). Geleneksel Yapı Elemanları. Yayımlanmamış ders notu. Yıldız Üniversitesi Mimarlık Fakültesi, Mimarlık Bölümü, Istanbul, Turkey.

Ateşli, E. (2017). Günümüz Heykel Sanatında Geleneksel Malzeme ve Yeni Arayışlar. (Yüksek Lisans Sanat Çalışması Raporu) YÖK Tez Merkezi veri tabanından erişildi.

Aydüz, S. (2004). Osmanlı Askeri Teknoloji Tarihi: Ateşli Silahlar. Türkiye Araştırmaları Dergisi, 2(4), 265-295.

Bal, B. C., Kılavuz, M. (2015). İlk Mobilya. Selçuk-Teknik Dergisi, Özel Sayı 1, 56-69.

Begiç H. N. (2017). Anadolu'da Yaşatılmaya Çalışılan Ahşap Oyuncak Üretimine Bir Örnek; Dedemin Oyuncakları Atölyesi. Motif Akademi Halkbilimi Dergisi, 10(19), 15-26.

Beydiz, M. G. (2017). Osmanlı Dönemi Gemi Yapımında Ağaç Kullanımı. Osmanlı Araştırmaları Dergisi, Sayı 2.

Bozkurt, N. (2007). Oymacılık. TDV İslâm Ansiklopedisi. (Cilt 34, ss. 13-15).

Bülbül, A. H., (2008). Anadolu Dini Mimarisinde Kalem İşi. İstanbul Büyükşehir Belediyesi Sanat ve Meslek Eğitim Kursları (İSMEK) El Sanatları Dergisi, Say1 5, 131-133.

Çalışkan, .Ö, Meriç, E., Yüncüler, M. (2019). Ahşap ve Ahşap Yapıların Dünü, Bugünü ve Yarını. Bilecik Şeyh Edebali Üniversitesi, Fen Bilimleri Dergisi, 6(1), 109-118.

Cartwright, M. (2017, December 08). Byzantine Icons. Ancient History Encyclopedia. Retrieved from https://www.ancient.eu/article/1161/

Casson, L.(1971). Ships and Seamanship in the Ancient World. Princeton, New Jersey, Princeton University Press.

Çorapçıŏlu, G.Ö. (2015). Doğu Karadeniz Örneğinde Su Değirmenlerinin Belgelenmesi ve Korunması Konusunda Bir Yöntem Araştırması. (Doktora Tezi) YÖK Tez Merkezi veri tabanından erişildi.

Demiriz, Y.(1989). Mimar Sinan'ın Yapılarında Kalem İşleri. Vakıf Haftası Dergisi, 6, 31-324.

Eroğlu, S. (2012). Burdur - Dengere Köyü Camisi'nin Ahşap Üzerine Kalemişi Bezemeleri. Uluslararası Sosyal Araştırmalar Dergisi, 6(25), 233-248.

ICOMOS (2017). Ahşap Mimari Mirasın Korunması İçin İlkeler. 19. ICOMOS Genel Kurulu.

Kerametli, C. (1961). Osmanlı Devri Ağaç İşleri, Tahta Oyma, Sedef, Bağ ve Fildişi Kakmalar. Türk Etnoğrafya Dergisi. Sayı 4, 5-13.

Kocabaş, U. (2014). Yenikapı Batıkları Kazısı ve Araştırmaları. TINA Denizcilik Arkeolojisi Dergisi, Sayı 1, $26-41$.

Kurtoğlu, A. (1984). Mobilya Yapımında Kullanılan Ağaç Malzemeler. Orman Fakültesi Dergisi, 34(2).

Kurtoğlu, A., Sofuoğlu, S. D., (2013). Mobilya Ve Ağaç Işslerinde Kullanılan Ahşap Malzemeler 1. II. Ulusal Mobilya Kongresi.

Orman Atlas1, (2013). Orman Genel Müdürlüğ̈̈ (OGM). Erişim adresi: https://www.ogm.gov.tr/ekutuphane/Yayinlar/Orman\%20Atlasi.pdf

Ormanlarımızda Yayılıș Gösteren Asli Ağaç Türleri. Orman ve Su İşleri Bakanlığl Orman Genel Müdürlüğü. Erişim adresi: https://www.ogm.gov.tr/ekutuphane/Yayinlar/Asli\%20A\%C4\%9Fa\%C3\%A7\%20T\%C3\%BCrleri.pdf

Önal, S. (1984). Müzik Aletleri Yapımında Kullanılan Yerli Ăgaç Türleri ve Özellikleri.Ormancılık Araştırma Esntitüsü Yayınları. Teknik Raporlar Serisi No: 17, 171-193.

Özdemir, Ü. (2015). Tarihte Türk Denizcilik Faaliyetleri ve Günümüz Limanlarının Gelișim Sürecine Olan Etkisinin Incelenmesi. SOBİAD, Türk Deniz Ticareti Sempozyumu VII. Karadeniz Limanları, Sempozyumu, Ordu.

Ritter, M. A. (1990). Timber Bridges Design, Construction, Inspection, and Maintenance. United States Department of Agriculture Forest Service, Washington, DC United States.

Sütiçem, M. (2008). Ülkemizde Şehiriçi Yaya Köprülerinde Malzeme Kullanımı Ve Detay Sorunlar. (Yüksek Lisans Tezi). YÖK Tez Merkezi veri tabanından erişildi.

Tetik Işık S., Uslu R., (2012). Türk Müziğinde Ağaç ve Çalg1 Yapım Bibliyografyası. Çevrimiçi Tematik Türkoloji Dergisi. 2(2), $24-41$.

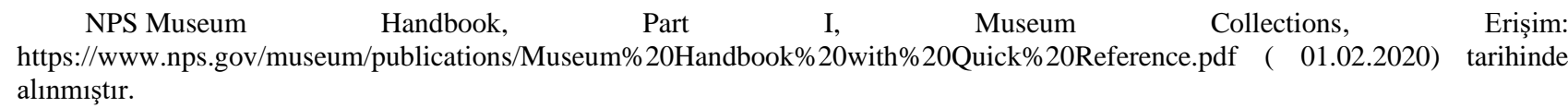

Yılmaz, S. Fidan, M. Apaydın, N. (2017). Türkiye'de Bulunan Tarihi Ahşap Köprülerin Yapım Sistemlerine Göre Sinıflandırılması. Uluslararası Katılımlı 6. Tarihi Yapıların Korunması ve Güçlendirilmesi Sempozyumu, Trabzon.

URL 1: https://www.sas.upenn.edu/ nmiller0/Tour_MM_circuit.Turkish.html Erişim tarihi: 20.01.2020

URL 2: https://www.trthaber.com/haber/kultur-sanat/antik-dunyanin-gizemli-yapilari-tumulusler-426212.html Erișim tarihi: 20.01 .2020 
URL3: https://karadeniz.gov.tr/bekdemir-mahallesi-camii/\#prettyPhoto[instagram]/16/ Erişim tarihi: 20.04.2020

URL 4: https://www.trthaber.com/haber/kultur-sanat/170-yillik-tarihi-yel-degirmeni-turizme-kazandirilacak-351656.html Erişim tarihi: 20.01 .2020

URL 5: http://www.ordukulturturizm.gov.tr/yazdir?47D05904ACCBD2D69700E809F7F8DFEC Erişim tarihi: 20.01.2020

URL 6: http://kopriyet.blogspot.com/2018/10/deretam-baskotan-koprusu.html Erişim tarihi: 03.02.2020

URL 7: https://en.wikipedia.org/wiki/Gordion_Furniture_and_Wooden_Artifacts Erişim tarihi: 21.01.2020

URL 8: https://islamansiklopedisi.org.tr/taht Erişim tarihi: 21.01 .2020

URL 9: https://www.britishmuseum.org/collection/object/W_1928-1010-1-a Erişim tarihi: 21.01.2020

URL 10: https://www.metmuseum.org/toah/works-of-art/1986.239/ Erişim tarihi: 21.01.2020

URL 11: https://en.wikipedia.org/wiki/Panel_painting Erişim tarihi: 20.01.2020

URL 12: https://en.wikipedia.org/wiki/Shigir_Idol Erişim tarihi: 22.01.2020

URL 13: https://tr.wikipedia.org/wiki/E\%C5\%9Frefo\%C4\%9Flu_Camii Erişim tarihi: 22.01.2020

URL 14: http://yenikapibatiklari.com/batiklar/eski-cagda-gemi-yapimi Erişim tarihi: 18.01.2020

URL 15: https://en.wikipedia.org/wiki/Pesse_canoe Erişim tarihi: 22.01.2020

URL 16: http://www.tinaturk.org/dergi/TINA_Dergi_Sayi_1/content/SAYI-1-2014-12-10.pdf Erişim tarihi: 18.01.2020

URL 17: https://en.wikipedia.org/wiki/Mechanical_toy Erişim tarihi: 27.01.2020

URL 18: https://www.metmuseum.org/toah/works-of-art/1974.28.94/ Erişim tarihi: 27.01.2020

URL 19: https://en.wikipedia.org/wiki/Clacton_Spear Erişim tarihi: 27.01.2020

URL 20: https://en.wikipedia.org/wiki/Wheel Erişim tarihi: 27.01.2020

URL 21: https://www.britannica.com/topic/ceremonial-object

URL 22: http://www.mevlanamuzesi.com/2016/11/10/rahle-selcuklu-1279-env-no-332/ Erişim tarihi: 27.01.2020

URL 23: https://islamansiklopedisi.org.tr/tufek Erişim Tarihi: 27.01.2020

URL 24: https://denizmuzesi.dzkk.tsk.tr/tr/content/465 Erişim tarihi: 28.01.2020

URL 25: https://www.elmundo.es/elmundo/2010/05/29/cultura/1275146085.html Erişim tarihi: 28.01.2020

URL 26: https://www.bursa.bel.tr/?sayfa=haber\&id=25379 Erişim tarihi: 28.01 .2020

URL 27: https://www.ogm.gov.tr/ekutuphane/Yayinlar/Asli\%20A\%C4\%9Fa\%C3\%A7\%20T\%C3\%BCrleri.pdf Erişim tarihi: 20.04 .2020

URL 28: https://rm.coe.int/090000168093e8b2 Erişim tarihi: 03.02.202 